\title{
Lucas Paradox, Declining Labor Share, Tendency of Rate of Profit to Fall of Karl Marx and Growth Theory of the Firm
}

\author{
Chao Chiung Ting ${ }^{1}$ \\ ${ }^{1}$ Graduated from Michigan State University, USA \\ Correspondence: Chao Chiung Ting, Graduated from Michigan State University, 6333 98th Place 1E, Rego Park, \\ NY 11374, USA. E-mail: tingtch7ti@aol.com
}

Received: June 5, 2020

Accepted: August 6, 2020

Online Published: August 10, 2020

doi:10.5539/ijef.v12n9p53

URL: https://doi.org/10.5539/ijef.v12n9p53

\begin{abstract}
Macroeconomic phenomena we observe are supposed to be analogous to conclusions derived from microeconomic models because macroeconomic phenomena are aggregation of data coming from microeconomic events. Since the firm plays the central role to produce output, I use growth theory of the firm to predict macroeconomic phenomena as below. First, the law of diminishing marginal product does not operate although marginal product derived from production function diminishes because the firm increases supply of output by scale growth without change in capital-labor ratio, not by change in capital-labor ratio under fixed scale. Thus, profit rate of rich (capital abundant) country is unnecessarily less than poor (labor abundant) country due to the law of diminishing marginal product so that capital does not outflow from rich country to poor country. Lucas' paradox is solved. Second, labor share is equal to capital share in the long run if capital and labor can substitute each other perfectly because the optimal capital-labor ratio of the firm is equal to the ratio of wage rate to return rate on capital, $K / N=w / \gamma$. That is, labor is relatively more expensive (less productive) than capital if labor share is greater than 50 percent. Since labor share has been higher than 50 percent of GDP (i.e., there is room to substitute capital for labor) for centuries, growth theory of the firm explains the long term trend of declining labor share. Third, labor share is countercyclical and capital share is cyclical in the short run because the amplitude of investment and profit fluctuation is greater than employment and wage. Fourth, the production function that the firm uses to produce is increasing return to scale, which implies not only cyclical co-movement of investment, employment, productivity and factor prices domestically but also unbalanced trade and factor price differentiation internationally. Fifth, diminishing marginal revenue makes wage growth rate less than growth rate of labor productivity and growth rate of return rate on capital less than growth rate of capital productivity. Sixth, growth theory of the firm asserts principle of acceleration in macroeconomics. Seventh, profit rate rises when GDP grows. Thus, tendency of rate of profit to fall predicted by Karl Marx is wrong. In appendix, I propose to statistically approximate the true production function in real world by Taylor series because production functions economists have ever proposed (e.g., Cobb-Douglas) are not proved to be true by economists.
\end{abstract}

Keywords: tendency of rate of profit to fall, lucas paradox, declining labor share, production function, increasing return to scale, diminishing marginal product, growth, growth of wage, growth of productivity

\section{Introduction}

In the beginning, growth theory is not a theory to derive effects on input factors from expansion of production possibility frontier (e.g., immiserizing growth in theory of international trade) but a branch of Keynesian economics to figure out the sufficient condition for new equilibrium when GDP in the sense of supply increases due to increase in capital stock by net investment, e.g., Domar (1947). To advance growth theory by establishing new mechanism of equilibrium restoration, Solow (1956) focused on adjustment in capital-labor ratio under both constant return to scale and the law of diminishing marginal product. That is, Solow constructed neoclassical theory of growth on Keynesian economics without any theoretical foundation based on growth theory of the firm from the view point of microeconomics. Consequently, neoclassical theory of growth omits effects arising from scale growth of the firm, especially increasing return to scale, on input factors (e.g., wage, employment, return rate on capital, change in capital (investment), marginal product, capital-labor ratio and change in labor share). Further, the volume of output generated by production function is supposed to be in physical terms (e.g., one ton 
steel and two pints wine) based on technology. But GDP is the aggregate output in terms of money (i.e., value added term). If we accept Solow (1956) which used aggregate production function in monetary terms to analyze GDP, we should be cautious about the distortion caused by the difference between physical terms and monetary terms (Note 1). For example, an automobile plant needs five thousand workers to produce one hundred thousand cars annually and the price of per car fluctuates so that the production function of the automobile plant in terms of total sales monetarily changes frequently but the production function of the automobile plant in terms of number of cars physically does not change.

The law of diminishing marginal product is indispensable for neoclassical theory of growth to determine optimal capital-labor ratio and stability of equilibrium. For example, full automation (i.e., no employment) is possible if marginal productivity of capital does not diminish so that economy is unstable due to no employment. The law of diminishing marginal product is also closely related to tendency of rate of profit to fall of Karl Marx, Lucas paradox and declining labor share. Assume that there are two countries with the same technology while one country is capital abundant and the other country is labor abundant. Theory of international trade demonstrates that capital abundant country will reallocate input factors in order to exploit its own advantage of affluent capital by producing more capital intensive good after two countries start to trade each other. Since firms substitute capital for labor in order to produce more capital intensive goods than before in capital abundant country, marginal product of capital in capital abundant country declines due to the law of diminishing marginal product. Conversely, return rate on capital will rise in labor abundant country. Thus, return rate on capital in capital abundant country will be lower than labor abundant country so that capital will outflow from capital abundant (rich) countries to labor abundant (poor) countries.

Lucas (1990) investigated the relationship between capital outflow and marginal product of capital by Cobb-Douglas production function under the assumption of constant return to scale and the law of diminishing marginal product. The marginal product of capital in India estimated by Lucas is about 58 times the marginal product of capital in US. But the fact is that capital does not empirically outflow from US to India as rapidly as the law of diminishing marginal product predicts. Thus, Lucas realized that 58, derived from Cobb-Douglas production function under neoclassical theory of growth, is a wrong number. As Karl Marx concerned that counteracting factors (e.g., extending working hours and higher exploitation rate) impedes tendency of rate of profit to fall in Capital Vol. III (Penguin 1990), Lucas proposed human capital and imperfection of capital market to revise his estimation about marginal product of capital. But Lucas did not argue that the law of diminishing marginal product is not an essential characteristic of the production function in rich country anymore after we introduce human capital and imperfection of capital market into economic model. Since the law of diminishing marginal product always operates, the possibility of capital outflows from rich country to poor country is not excluded theoretically by Lucas. Thus, human capital and imperfection of capital market does not actually handle the contrary between the law of diminishing marginal product and capital immobility from the view point of economic theory.

The law of diminishing marginal product of capital states that if the volume of capital increases and the volume of labor are given, then marginal product of capital decreases. Consequently, high capital-labor ratio suggests low marginal product of capital because high capital-labor ratio implies that the volume of capital increases while the volume of labor is given. But the actual marginal product of capital we observe in real world is not necessary to decrease even the law of diminishing marginal product of capital is an essential characteristic of production function because the firm can alternatively increase supply of output by scale growth without change in capital-labor ratio instead of change in capital-labor ratio under fixed scale. For example, marginal product of capital does not diminish when the firm expands by scale to produce more output than before while the production function of the firm is constant return to scale. Since economic agents will adjust if economic agents are not optimal, microeconomic equilibrium is the sufficient condition for macroeconomic equilibrium. Thus, neoclassical theory of growth is unsound and incomplete because neoclassical theory of growth does not show us that the firm is on the position that both capital-labor ratio and scale of the firm are optimal in the sense of microeconomics whenever capital-labor ratio in the sense of macroeconomics is optimal in neoclassical theory of growth.

Like neoclassical theory of growth, Karl Marx made the same mistake about capital-labor ratio. In Capital Vol. III, Karl Marx listed numerical examples in which surplus-rate, which is equivalent to profit rate in the theoretical framework of modern economics, falls if the ratio of constant capital to variable capital rises in Chapter 13. Notice that growth of capital accumulation by investment leads to growth of depreciation while depreciation is a component of constant capital. Consequently, high capital-labor ratio in the sense of Karl Marx implies that labor time contained in a single unit product is less than before because the firm substitutes capital 
for labor so that the number of worker the firm employs is less than before but produces the same quantity of output as before. According to labor theory of value, profit is equivalent the volume of labor time exploited by capitalists. Thus, both surplus-value (profit) and surplus-rate (profit rate) fall as capital-labor ratio in the sense of Karl Marx rises when exploit rate is given. Although Karl Marx recognized that capital-labor ratio rose in $19^{\text {th }}$ century and capitalists pursue profit, Karl Marx did not explain why capitalists substitute high capital-labor ratio (i.e., high depreciation) production method with low profit rate for low capital-labor ratio production method with high profit rate as well as why capitalists do not stop accumulating capital when capitalists anticipate that profit rate will fall if capitalists increase supply of output by investment (i.e., capital accumulation). Marxists may argue that business cycle is the empirical evidence to demonstrate that capitalists intend to accumulate capital and increase supply of output continuously and unlimitedly. But Marxists ignore the fact that overproduction reflects the miscalculation of rational capitalists, not the incentive. During overproduction, rational capitalists contract production by lay-off workers and stop capital accumulation by reducing investment, which are two essential characteristics of recession. Thus, rational capitalists do not have incentive to create overproduction on purpose because overproduction hurts capitalists' own interest. Marxists may also argue that competition will drive profit rate to fall continuously. But Karl Marx expressed profit rate equalization in Capital Vol. III and condemned extraordinarily high profit arising from monopoly under capitalism. Thus, capitalism's profit rate would not approach to zero under both monopoly and profit rate equalization if we overview theoretical framework of Karl Marx in Capital as a whole rather than approaches to zero if we restrict ourselves to focus on tendency of rate of profit to fall.

To take care of Lucas' paradox and tendency of rate of profit to fall, I will follow Ting $(2010$, 2018). Ting showed that the firm pursues maximum return rate on capital instead of maximum profit because return rate on capital allocates resources, not profit in terms of absolute amount. Under maximum return rate on capital hypothesis, the best strategy of the firm, which responds to increase (decrease) in demand for its own outputs under given technology, is to grow (contract) by scale (i.e., determine optimal size of the firm) instead of adjustment in capital-labor ratio under given scale. In other words, return rate on capital under flexible scales is always greater than flexible capital-labor ratio under given scale. Thus, decision about the firm's size in the sense of business management eliminates the possibility that the law of diminishing marginal product operates so that we are not going to observe diminishing marginal product in real world even the law of diminishing marginal product is an essential characteristic of the production function of the firm. Consequently, both the volume of each input factor that will be employed by the firm and the reward of each input factor that will be paid by the firm are dealt by growth theory of the firm under flexible scale, not by economic theory under flexible capital-labor ratio and given scale. Since macroeconomic phenomena result from aggregation of microeconomic data, we can use growth theory of the firm to predict what capital-labor ratio, marginal product of capital, return rate on capital and labor share will be observed by us in the sense of macroeconomic phenomenon. Besides, both propensity to save and population growth rate do not matter in growth theory of the firm because microeconomics does not require that full employment equilibrium, in the sense of Keynesian economics, should be maintained as neoclassical theory of growth does.

In addition, I will demonstrate that the firm absolutely uses technology of increasing return to scale to produce outputs in physical terms under maximum return rate on capital hypothesis. This conclusion is natural because increasing return to scale is more profitable than constant return to scale so that the firm selects technology of increasing return to scale definitely. Market will establish equilibrium under maximum return rate on capital hypothesis even production function is increasing return to scale because the size of the firm is limited by limited market demand for goods. Besides, Romer (1986) demonstrated that equilibrium exists under the circumstance of increasing return to scale and Krugman $(1979,1991)$ considered the relationship between increasing return to scale and international trade in economic geography. Thus, economy is stable under increasing return to scale theoretically. Moreover, empirical evidences support increasing return to scales e.g., Chen (2015), Morrison and Siegel (1997). Further, Wheelock and Wilson (2011) found increasing return to scale in manufacturing and banking while Grabowski and Sanchez (1986), Vergos et al. (2010) and Oliveira et al. (2006) confirmed increasing return to scale in agriculture.

It is worth noting that Solow (1956) wrote in the beginning that "A "crucial" assumption is one on which the conclusions do depend sensitively, and it is important that crucial assumptions be reasonably realistic. When the results of a theory seem to flow specifically from a special crucial assumption, then if the assumption is dubious, the results are suspect" Since both marginal product of capital and return rate on capital will not diminish if the firm grows by scale, production function in which marginal product of capital diminishes does not guarantee that marginal product of capital diminishes in real world. Thus, the law of diminishing marginal product of capital 
and constant return to scale are two crucial but dubious assumptions in Lucas (1990).

Since growth theory of the firm determines both the volume of each input factor the firm employs and the reward to each input factor the firm pays, growth theory of the firm can analyze the share of each input factor. Instead of the growth theory of the firm, Piketty (2014) used neoclassical theory of growth to study declining labor share.

In Solow (1956), equation (6) states $\frac{F(K, L)}{K}=\frac{n}{s}$ where $K$ is capital, $L$ is labor, $F$ is production function, $F(K, L)$ is net national income, $s$ is propensity to save of net national income and $n$ is population growth rate. Piketty explained declining labor share by his second law $(\beta)$ : the ratio of capital to GDP (capital-income ratio) is equal to the ratio of propensity to save to population growth rate, $\frac{K}{F(K, L)}=\frac{s}{n}$. Piketty converted Solow's equation (6) into his second law. Then, we get Piketty's first law: $\frac{\gamma K}{F(K, L)}=\frac{\gamma s}{n}$, where $\frac{\gamma K}{F(K, L)}$ is capital share and $\gamma$ is return rate on capital. But Piketty's the first law has a fatal shortcoming because Piketty was not able to explain why labor share is countercyclical and capital share is cyclical in the short run by his second law. Consequently, Piketty emphasized that he developed a theory to determine labor share and capital share in the long run, not in the short run. Notice that Solow (1956) is long run theory because capital is in equilibrium in neoclassical theory of growth while Keynesian economics is short run equilibrium because capital may be in disequilibrium. That is, short run equilibrium is the sufficient condition for long run equilibrium because the volume of capital is not optimal if the volume of investment is not optimal. Thus, Piketty (2014) is incomplete and unsound because Piketty omitted short run theory of capital share and labor share.

Krusell and Smith (2014), Rognlie (2014) and Jones (2014) empirically studied declining labor share and found that declining labor share is critically dependent on depreciation. Solow (1956) regarded net national income while net national income is equal to GDP minus depreciation. Since Piketty substituted the propensity to save of GDP for the propensity to save of net national income as well as replaced net capital by gross capital, Piketty (2014) overestimated both propensity to save and capital. Further, the concept of capital in Piketty (2014), which included capital gain and residential housing, is inconsistent with the concept of capital in Solow (1956), which is related to production only. Capital gain does not increase the volume of physical capital so that capital gain does not make GDP grow in the sense of supply. Residential housing is also not the capital which can produce goods for selling in the sense of GDP. Thus, Piketty overestimated capital-income ratio and this overestimation leads Rognlie (2015) to find that increase in capital share turns out to come entirely from the house sector.

As Lucas (1990), the law of diminishing marginal product of capital misleads Piketty and Zucman (2014), too. Piketty and Zucman (2014, p.1303) wrote "when there is more capital, the rate of return to capital must go down." It leads Piketty and Zucman to argue that capital share grows because the growth of capital-income ratio is greater than the decrease in marginal product of capital (e.g., decrease in population growth rate leads to increase in capital-income ratio even return rate on capital falls due to the law of diminishing marginal product). Since I point out that Piketty overestimated capital in the last paragraph and return rate on capital does not diminish due to scale growth above, I reject Piketty and Zucman (2014). Besides, Piketty argued that elasticity of substitution between capital and labor is greater than one so that labor share declines but Lawrence (2015) and Schneider (2011) reviewed empirical studies and reported that elasticity of substitution between capital and labor is less than one.

Piketty and Zucman (2014) used Cobb-Douglas production function to study capital share empirically. If the return rate on capital is equal to marginal product of capital, the return rate on capital of Cobb-Douglas production function is equal to $\alpha K^{\alpha-1} L^{1-\alpha}$. Piketty's $\beta$ is equal to $K / Y=1 / K^{\alpha-1} L^{1-\alpha}$. Thus, the capital share under Cobb-Douglas production function is always equal to $\alpha$ (i.e., there is no declining labor share in both the short run and the long run) even exogenous change in $s / n$ causes change in capital-income ratio because the effect caused by exogenous change in propensity to save and population growth rate on capital-income ratio is offset by the effect caused by exogenous change in propensity to save and population growth rate on marginal product of capital. For instance, rise in propensity to save leads to larger capital $(K)$ than before so that $1 / K^{\alpha-1} L^{1-\alpha}$ falls and $\alpha K^{\alpha-1} L^{1-\alpha}$ rises. Thus, there is no causal relationship between capital 
share and $s / n$ under Cobb-Douglas production function because Cobb-Douglas production function determines capital share by itself. Consequently, Piketty and Zucman are self-contradictory because Cobb-Douglas production function requires that capital share should be constant in the short run as well as in the long run but Piketty and Zucman used Cobb-Douglas production function to estimate declining labor share empirically. To summarize, Piketty and Zucman discovered numerical relationships (correlation) among capital share, return rate on capital, propensity to save and population growth rate under Cobb-Douglas production function statistically instead of causal relationships scientifically so that these numerical relationships discovered by Piketty and Zucman are as meaningless as the positive correlation between drowning rate and ice cream sales. Note that both drowning rate and ice cream sales are related to temperature positively.

It is worth noting that Piketty (2014) criticized Marx's infinite capital accumulation. Under theoretical framework of Capital, capital share should decline in the long run because infinite capital accumulation should make profit rate approach to zero according to tendency of rate of profit to fall. But Piketty observed increase in capital share, which is equivalent to declining labor share, in the long run. Thus, Piketty and Karl Marx are opposite to each other.

Since tendency of rate of profit to fall of Karl Marx, Lucas (1990) and Piketty (2014) are incomplete and unsound, the objective of this paper is to reply tendency of rate of profit to fall, Lucas paradox and declining labor share by demonstrating three statements under given technology and without counteracting factors concerned by Karl Marx. First, firm grows by scale so that marginal product of capital does not diminish in real world even if diminishing marginal product of capital is an essential characteristic of the production function. In other words, profit rate is not necessary to fall under growth in the sense of macroeconomics. Second, labor share is equal to capital share in the long run because the firm can substitute capital for labor and vice versa. Third, labor (capital) share is countercyclical (cyclical) in the short run because investment and profit fluctuate greater than employment and wage respectively during business cycle. By these three statements above, I reach two conclusions. First, capital does not outflow rapidly from rich region (country) to poor region (country) domestically (internationally) and profit rate does not fall to zero because both marginal product of capital and return rate on capital does not decrease due to the reason that the firm grows by scale and production function is increasing return to scale. Thus, both Lucas paradox and tendency of rate of profit to fall of Karl Marx are denied by growth theory of the firm. Second, there is long term trend of declining labor share domestically and globally although labor share is up and down in the short run because both domestic labor share and global labor share have been greater 50 percent for centuries so that there is room to substitute capital for labor.

In appendix, I will discuss empirical estimation of aggregate production function for two reasons. First, we do not know the true specification (i.e., true functional form) of production function. Second, the concept of production function is the corner stone of this paper. For example, many economists derive theoretical conclusions (e.g., steady state of growth) from Cobb-Douglas production function and estimate aggregate production function based Cobb-Douglas function empirically. But Sebastian et.al (2019), Antràs (2004) and Duffy and Papageorgiiou (2000) denied that Cobb-Douglas function is the true specification of aggregate production function because the elasticity of substitution between capital and labor estimated by them is significantly different from one while Cobb-Douglas production function requires that elasticity of substitution should be equal to one. In other words, the aggregate production function (e.g., Cobb-Douglas production function), estimated by us, must fit properties of aggregate production function derived from theoretical model (e.g., maximum profit, minimum cost and maximum return rate on capital), which is the issue of functional form highlighted by Diewert (1971). Since we also do not know what the true economic model is, the approach of functional form still fails to identify the true specification of production function. Thus, we need a method to estimate production function accurately even we do not know the true specification of production function.

Taylor series means that we can approximate any function by polynomial function. For example, $f(N, K)=$ $\frac{\partial f}{\partial N} N+\frac{\partial f}{\partial K} K$ is the first order of Taylor series of production function $f(K, N)$ expanding at point $(0,0)$ while $f(0,0)=0$ (i.e., no input, no output). If production is linear, $\frac{\partial f}{\partial N}$ and $\frac{\partial f}{\partial K}$ will be only two statistically significant coefficients estimated by us. Thus, we can use Taylor series to estimate production function in terms of polynomial function statistically even we do not know what the true specification of production function is. Therefore, I suggest that we would use Taylor series to empirically approximate the statistical specification of 
the true production function rather than estimate production function based on prior information like Cobb-Douglas function.

\section{Model}

I assume that the firm produces single product instead of varieties in order to avoid the problem of output aggregation and express production function in physical terms, not sales. Regularly, demand for good is represented by the equation that price multiplies quantity. Ting (2018) used $P Q$ and $(P-c) Q$ to represent two parallel demand curves, where $c$ represents the vertical distance between two parallel demand curves and the domain of variable $c$ is positive real number. The larger $c$ is, the greater leftward shifting in demand curve. By mathematically studying the effect stemming from change in $c$ (e.g., shifting in demand curve in the sense of microeconomics which is caused by change in GDP) on marginal product of capital, return rate on capital, change in volume of capital (investment), marginal product of labor, wage, employment, labor share and capital share, we shall economically understand the effect, stemming from shifting in demand curve on input factors, on real world by growth of the firm. I assume that firms use capital and labor to produce output in this paper intending to ignore intermediate goods. Labor is paid by wage. Capital is compensated by the residual: sale revenue minus wage expenditure. Thus, we have two definitions

$$
\begin{gathered}
(P-c) Q=w N+r K \\
r=\frac{(P-c) Q-w N}{K}
\end{gathered}
$$

Where $w, N, \gamma$, and $K$ are wage rate, labor, return rate on capital and capital respectively. Equation (1) means that sales revenue will be distributed into labor and capital. Equation (2) defines what return rate on capital is. Equation (1) and (2) are equivalent because we can transform one into the other. Return on capital is composed of profit and depreciation. Note that I assume that the firm does not borrow in this paper so that the total asset, which is equivalent to the volume of capital in terms of money to run the firm (i.e., the $K$ in equation (1)), is equal to equity in this paper. Otherwise, Ting (2012) demonstrated that borrowing is financial leverage to raise return rate on equity while the sum of borrowing and equity is equal to total asset. Thus, the return rate on total asset appraises efficiency of the firm and maximum return ate on equity is the objective of the firm.

Ting (2010) argued that maximum profit does not guarantee that return rate on capital is maximized. Since return rate on capital instructs entrepreneurs to allocate their resources, the objective of the firm is to maximize return rate on capital, not maximum profit. Following Ting (2010), we get

$$
\begin{gathered}
\operatorname{Max} \frac{(P-c) Q-w N}{K} \\
k=\frac{(P-c) Q-w N}{\left((P-c)+Q \frac{\partial P-c}{\partial Q}\right) \frac{\partial Q}{\partial K}}\left(B y \frac{\partial \frac{(P-c) Q-w N}{K}}{\partial K}=0\right) \\
N=\frac{(P-c) Q-\gamma K}{w}=\frac{(P-c) Q-\gamma K}{\left((P-c)+Q \frac{\partial P-c}{\partial Q}\right) \frac{\partial Q}{\partial N}} \\
w=\left[(P-c)+Q \frac{\partial P-c}{\partial Q}\right] \frac{\partial Q}{\partial N}=(P-c)\left(1+\frac{1}{\eta}\right) \frac{\partial Q}{\partial N}\left(B y \frac{\partial \frac{(P-c) Q-w N}{K}}{\partial N}=0\right) \\
r=\left[(P-c)+Q \frac{\partial P-c}{\partial Q}\right] \frac{\partial Q}{\partial K}=(P-c)\left(1+\frac{1}{\eta}\right) \frac{\partial Q}{\partial K}\left(B y K=\frac{(P-c) Q-w N}{\left[(P-c)+Q \frac{\partial P-c}{\partial Q}\right] \frac{\partial Q}{\partial K}}=\frac{\gamma K}{\left[(P-c)+Q \frac{\partial P-c}{\partial Q}\right] \frac{\partial Q}{\partial K}}\right) \\
\frac{K}{N}=\frac{(P-c) Q-w N}{(P-c) Q-\gamma K} \frac{\frac{\partial Q}{\partial N}}{\frac{\partial Q}{\partial K}}=\frac{\gamma K}{w N} \frac{\frac{\partial Q}{\partial N}}{\frac{\partial Q}{\partial K}}\left(i . e ., \frac{w}{\gamma}=\frac{\frac{\partial Q}{\partial N}}{\frac{\partial Q}{\partial K}}=\frac{\partial K}{\partial N}\right)
\end{gathered}
$$

Notice that I do not derive any theorem from equation (1) and equation (2) because all theorems in this section are derived from maximum return rate on capital hypothesis, equation (3). In other words, $K, N, w$ and $\gamma$ are endogenous and dependent variable (effect) while maximum return rate on capital hypothesis is exogenous and independent variable (i.e., cause). Otherwise, this paper is false because there are violations of circular reasoning (e.g., volume of labor is independent variable to determine volume of capital in equation (4) while volume of capital is independent variable to determine volume of labor in equation (5)). In short, relationships among $K$, $N, w$ and $\gamma$ are mathematical mapping, not causation.

The left hand side of equation (6) is the wage expenditure to utilize a single unit labor while the right hand side represents revenue accruing from utilization of a single unit labor. Thus, wage is related to marginal revenue. But 
the effect stemming from marginal revenue on reward to input factor is omitted by neoclassical economics. In other words, economists mistake marginal product for reward to input factor in neoclassical theory of growth. It is a common puzzle in economics that growth rate of labor productivity is usually greater than growth rate of both real wage and nominal wage. In equation (6), $1+1 / \eta<1$ bexplains this puzzle because growth of wage is less than growth of marginal product of labor. Similarly, equation (7) reminds economists that growth of return rate on capital is supposed to be less than growth of capital productivity. Since equation (4) and equation (5) tells us the volume of capital and the volume of labor that the firm plan to employ under maximum return rate on capital respectively, equation (8) represents the optimal capital-labor ratio when the firm practices production under maximum return rate on capital hypothesis. When capital-labor ratio is in equilibrium, we have

$$
\begin{gathered}
\frac{d \bar{N}}{d t}=\frac{\frac{d k}{d t} N-\frac{d N}{d t} K}{N^{2}}=0 \\
\frac{K}{N}=\frac{d K}{d N}=\frac{\Delta K}{\Delta N} \\
\frac{\Delta K}{\Delta N}=\frac{\frac{\partial Q}{\partial N}}{\frac{\partial Q}{\partial K}}=\frac{(P-c)\left(1+\frac{1}{\eta}\right) \frac{\partial Q}{\partial N}}{(P-c) P\left(1+\frac{1}{\eta}\right) \frac{\partial Q}{\partial K}}=\frac{w}{r}=\frac{K}{N}
\end{gathered}
$$

In equation (9), $t$ represents time. Equation (11) is derived from equation (8) and equation (10). Equation (11) means that the ratio of wage rate to return rate on capital is equal to capital-labor ratio. For example, the optimal capital-labor ratio is 2 if the marginal product of labor doubles marginal product of capital. It implies that two units capital can replace one unit labor as well as wage rate doubles return rate on capital. Equation (8) and equation (11) demonstrate that we can derive the optimal capital-labor ratio by two different methods. In equation (11), capital-labor ratio, the ratio of labor marginal product to capital marginal product and the ratio of wage rate to return rate on capital are effect caused by maximum return rate on capital hypothesis. As Ting (2018) argued that price cannot explain quantity and quantity cannot explain price because supply and demand determine not only price but also quantity (i.e., both price and quantity are dependent variable), it is wrong that we use marginal product to explain both the ratio of wage rate to return rate on capital and capital-labor ratio as well as vice versa because maximum return rate on capital hypothesis is cause (independent variable) while both marginal product and capital-labor ratio are effect (dependent variable). The meaning of equation (11) is mathematical mapping among dependent variables, not causation. Equation (11) indicates that economy converges into equilibrium when capital-labor ratio, the ratio of wage rate to return rate on capital and the ratio of marginal product of labor to marginal product of capital converge. Otherwise, equation (11) tells us that economy is in disturbance because capital-labor ratio, the ratio of wage rate to return rate on capital and the ratio of marginal product of labor to marginal product of capital diverge.

$$
\begin{gathered}
r K=w N \\
P Q=w N+\gamma K=P\left(1+\frac{1}{\eta}\right)\left(\frac{\partial Q}{\partial N} N+\frac{\partial Q}{\partial K} K\right)
\end{gathered}
$$

Equation (12) is derived from equation (11), which demonstrates that capital share is equal to labor share when economy reaches long run equilibrium. Equation (13) is derived from equation (1), equation (6) and equation (7). By equation (13), we get

$$
Q=\left(1+\frac{1}{\eta}\right)\left(\frac{\partial Q}{\partial N} N+\frac{\partial Q}{\partial K} K\right)
$$

In equation (14), production function is in physical terms (i.e., how many quantity of output is produced in physical terms like ounce and piece). Equation (14) is always greater than zero in real world because the firm will not expand production if price elasticity is greater than -1 due to the reason that the more quantity of output the firm produces and sells, the less total revenue the firm receives. If production function is constant return to scale, then we have $Q=\frac{\partial Q}{\partial N} N+\frac{\partial Q}{\partial K} K$. It suggests that the firm operates production function of constant return to scale if market is competitive (i.e., $\eta=-\infty$ ). Since $1+\frac{1}{\eta}<1$, equation (13) and equation (14) imply increase return to scale whether output is in terms of money or in physical terms.

$$
Q(t K, t N)=t^{n} Q(K, N)
$$




$$
\begin{gathered}
\frac{\partial t^{n} Q(K, N)}{\partial K}=t^{n} \frac{\partial Q(K, N)}{\partial K}=\frac{\partial Q(t K, t N)}{\partial t K} \frac{\partial t K}{\partial K}=\frac{\partial Q(t K, t N)}{\partial t K} t \\
t^{n-1} \frac{\partial Q(K, N)}{\partial N}=\frac{\partial Q(t K, t N)}{\partial t N} \\
\frac{\partial Q(t K, t N)}{\partial t}=\frac{\partial Q(t K, t N)}{\partial t K} K+\frac{\partial Q(t K, t N)}{\partial t N} N=\frac{\partial t^{n} Q(K, N)}{\partial t}=n t^{n-1} Q(K, N) \\
n t^{n-1} Q(K, N)=t^{n-1} \frac{\partial Q(K, N)}{\partial K} K+t^{n-1} \frac{\partial Q(K, N)}{\partial N} N \\
Q(K, N)=\left(1+\frac{1}{\eta}\right)\left(\frac{\partial Q(K, N)}{\partial K} K+\frac{\partial Q(K, N)}{\partial N} N\right)=\left(1+\frac{1}{\eta}\right) n Q(K, N) \\
n=\frac{1}{1+\frac{1}{\eta}} \text { and } n>1 \text { if } \eta<-1
\end{gathered}
$$

In order to approximate quantity of real output, economists usually deflates sales and nominal GDP. Klette and Griliches (1996) argued that price deflation leads to underestimate scale estimator because price elasticity is omitted by economists. They found that scale range $(1.1,1.06)$ corresponds to price elasticity range $(-6,-12)$. By equation (21), scale range I infer is $1.09(-12)$ and $1.2(-6)$. Klette and Griliches used Cobb-Douglas function to estimate empirical scale estimator. But I will explain in appendix that Cobb-Douglas function leads to constant return to scale. In other words, Cobb-Douglas function itself is another source of bias which leads to underestimate scale estimator in empirical studies of return to scale. Thus, scale estimator in the empirical study of Klette and Griliches is underestimated. Since equation (21) is independent of Cobb-Douglas function, it leads my scale range inferred from equation (21) is greater than Klette and Griliches. However, the empirical study of Klette and Griliches supports the theoretical frame work of this paper, which demonstrates the relationship between return to scale and price elasticity exhibited in equation (21).

Increasing return to scale makes productivity rise (fall) by the rate of $t^{\frac{1}{1+\frac{1}{\eta}}}$ without technology progress when GDP grows (contracts). Is there an empirical evidence to support the meaning of equation (14) that increasing return to scale explains why productivity grows without technology progress when GDP grows? In other words, would increase return to scale explain Lucas paradox rather than technology progress like advance human capital? Liu et.al (2011) stated clearly in abstract "It is found that all of the selected sectors in manufacturing industry in China show increasing return to scale. And most of these sectors experience negative or zero technical change, which implies that economic growth in Chinese manufacturing industry over recent two decades has largely driven by increasing return to scale rather than technical progress." In addition, both productivity and marginal product, which we are going to observe in real world, are cyclical instead of diminishing because the firm adjusts scale to respond change in GDP while change in GDP drives demand curve to shift (i.e., drives $c$ to change).

$t^{\frac{1}{1+\frac{1}{\eta}}}$ indicates the degree of increasing return to scale. Since marginal revenue diminishes fast (slow) if the absolute value of price elasticity is small (large), productivity must grow fast (slow) in order to offset fast (slow) decrease in marginal revenue. Thus, the small (great) absolute value of price elasticity corresponds to the great (small) increase in productivity by increasing return to scale. This correspondence predicts two microeconomic phenomena. First, the degree of increasing return to scale is positively correlated with the degree of market concentration because the higher degree of increasing return to scale (i.e., the larger optimal size of the firm), the fewer firms in market. Second, the degree of increasing return to scale is negatively correlated with price elasticity because the higher degree of increasing return to scale, the less competition (i.e., the demand curve of each firm becomes steeper).

$$
\frac{\partial K}{\partial c}=\frac{\partial \frac{(P-c) Q-w N}{\left((P-c)+\frac{\partial P-c}{Q}\right) \frac{\partial Q}{\partial K}}}{\partial c}=\frac{-Q(P-c)\left(1+\frac{1}{\eta}\right) \frac{\partial Q}{\partial K}+\left(1+\frac{1}{\eta}\right) \frac{\partial Q}{\partial K} \gamma K}{\left((P-c)\left(1+\frac{1}{\eta}\right) \frac{\partial Q}{\partial K}\right)^{2}}=\frac{\gamma\left(-Q+\left(1+\frac{1}{\eta}\right) \frac{\partial Q}{\partial K} K\right)}{\gamma^{2}}=\frac{-\left(1+\frac{1}{\eta}\right) \frac{\partial Q}{\partial N} N}{\gamma}<0
$$




$$
\begin{gathered}
\frac{\partial N}{\partial c}=\frac{-\left(1+\frac{1}{\eta}\right) \frac{\partial Q}{\partial K} K}{w}<0 \\
\frac{\partial K}{\frac{\partial c}{\partial c}}=\frac{w \frac{\partial Q}{\partial N} N}{\gamma \frac{\partial Q}{\partial K} K}=\frac{\Delta K}{\Delta N}=\frac{\partial K}{\partial N}=\frac{K}{N}=\frac{\frac{\partial Q}{\partial N}}{\frac{\partial Q}{\partial K}}=\frac{w}{\gamma}
\end{gathered}
$$

By equation (22) and equation (23), the firm always increases (decrease) both capital and labor simultaneously when demand curve shifts rightward (leftward). It implies that both employment and investment are cyclical, which complies with business cycles we have observed. In other words, business cycle is a phenomenon of change in economic scale. Besides, equation (22) implies principle of acceleration in macroeconomics because the firm invests when demand increases (i.e., aggregate investment is induced by increase in GDP). Since equation (24) confirms that capital-labor ratio does not change after capital changes by $\frac{\partial K}{\partial c}$ and labor changes by $\frac{\partial N}{\partial c}$ under the circumstance of change in market demand because the ratio of change in capital to change in labor is equal to capital-labor ratio, the optimal strategy of the firm is to grow (shrink) by scale with fixed capital-labor ratio when demand curve shifts with parallel rightward (leftward).

By equation (4), we get

$$
\begin{gathered}
\frac{\partial Q}{\partial K}=\frac{(P-c) Q-w N}{\left((P-c)+Q \frac{\partial P-c}{\partial Q}\right) K}=\frac{(P-c) Q-w N}{(P-c)\left(1+\frac{1}{\eta}\right) K} \\
\frac{\partial \frac{\partial Q}{\partial K}}{\partial c}=\frac{-Q(P-c)\left(1+\frac{1}{\eta}\right) K+\left(1+\frac{1}{\eta}\right) K r K}{\left((P-c)\left(1+\frac{1}{\eta}\right) K\right)^{2}}=\frac{(P-c)\left(1+\frac{1}{\eta}\right) K\left(-Q+\left(1+\frac{1}{\eta}\right) \frac{\partial Q}{\partial K} K\right)}{\left((P-c)\left(1+\frac{1}{\eta}\right) K\right)^{2}}<0
\end{gathered}
$$

By equation (5), we get

$$
\begin{gathered}
\frac{\partial Q}{\partial N}==\frac{(P-c) Q-r K}{\left[(P-c)+Q \frac{\partial P-c}{\partial Q}\right] N} \\
\frac{\partial \frac{\partial Q}{\partial N}}{\partial c}==\frac{(P-c)\left(1+\frac{1}{\eta}\right) N\left(-Q+\left(1+\frac{1}{\eta}\right) \frac{\partial Q}{\partial N} N\right)}{\left((P-c)\left(1+\frac{1}{\eta}\right) N\right)^{2}}<0
\end{gathered}
$$

Equation (26) and equation (28) also conclude that both marginal product of capital and marginal product of labor are cyclical under growth of the firm without technical progress. Notice that this conclusion is consistent with the conclusion that marginal productivity is cyclical under increasing return to scale above. Thus, we are supposed to observe that wage rate and return rate on capital as well as marginal product of labor and marginal product of capital are positively correlated. It is crucial that when the firm grows by scale under increasing return to scale, both the absolute quantity of labor marginal product and the absolute quantity of capital marginal product rise proportionally by $t^{\frac{1}{1+\frac{1}{\eta}}}$ so that the ratio of marginal product of labor to marginal product of capital does not change. This conclusion implies that we are not allowed to infer absolute wage and absolute return rate on capital from the ratio of wage rate to return rate on capital, which is equivalent to the relative price between labor and capital.

$$
\begin{gathered}
\frac{\partial \gamma}{\partial c}=\frac{\partial(P-c)\left(1+\frac{1}{\eta}\right) \frac{\partial Q}{\partial K}}{\partial c}=-\left(1+\frac{1}{\eta}\right) \frac{\partial Q}{\partial K}<0 \\
\frac{\partial w}{\partial c}=-\left(1+\frac{1}{\eta}\right) \frac{\partial Q}{\partial N}<0 \\
\frac{\partial \gamma}{\partial w}=\frac{\frac{\partial Q}{\partial K}}{\frac{\partial Q}{\partial N}}=\frac{\gamma}{w}=\frac{N}{K}
\end{gathered}
$$

Equation (29) and equation (30) demonstrate that both return rate on capital and wage rate are cyclical. Thus, 
return rate on capital will not diminish under growth so that capital will not outflow from rich country to poor country. Similarly, wage rate will be higher than subsistence if the firm grows so that it is wrong that Karl Marx argue wage is equal to subsistence. Equation (31) means return rate on capital and wage rate change proportionally when the firm grows by scale so that the ratio of return rate to wage rate are fixed but absolute return rate on capital and absolute wage rate rise. That is, I demonstrate that we cannot infer absolute prices from relative prices but we can infer relative prices from absolute prices as Ting (2018) concluded. Thus, relative price is dubious so that result based on relative price is suspicious (i.e., economic analysis in which absolute price is excluded is incompletely and unsound definitely) and I will use comparative advantage of David Ricardo (1817) to be an example for demonstration in the last section.

$$
\frac{r K}{w N}=\frac{\frac{\gamma}{w}}{\frac{N}{K}}=\frac{(P-c)\left(1+\frac{1}{\eta}\right) \frac{\partial Q}{\partial K} K}{(P-c)\left(1+\frac{1}{\eta}\right) \frac{\partial Q}{\partial N} N}=\frac{\partial N}{\partial K} \frac{K}{N}=\frac{\frac{\partial N}{\partial K}}{\frac{N}{K}}=\frac{\frac{\Delta N}{N}}{\frac{\Delta K}{K}}=\frac{\frac{\frac{\partial Q}{\partial Q}}{\partial N}}{\frac{N}{K}}
$$

Equation (12) is inappropriate to explain change in capital share and labor share in the short run. Instead, equation (32) is helpful for economists to study time series of change in capital share and labor share in the short run because we can use different indexes to test change in capital share and labor share. First, the second index and the seventh index suggests that capital share rises and labor share falls when increase in the ratio of marginal capital product (return rate on capital) to marginal labor product (wage rate) is greater than increase in labor-capital ratio. Second, the sixth index means that capital share rises and labor share falls when employment growth rate is greater than capital growth rate. In other words, we get cyclical capital share and countercyclical labor share if change in capital (investment) fluctuates greater (less) than change in employment during recession (boom). Equation (23) demonstrates that marginal product of capital is cyclical because marginal product of capital rises (falls) when demand curve shifts rightward (leftward). When marginal product of capital increases (decrease), it implies return rate on capital rises (falls) by equation (6). Return rate on capital consists of profit rate and depreciation rate. Since profit rises in boom and falls in recession and return rate on capital depends on marginal product of capital as well as marginal revenue, capital share is supposed to be cyclical. The third index indicates that capital share is cyclical if profit rate drops (rises) greater (less) than wage rate in recession (boom). There are empirical evidences to support the explanation of cyclical capital share and countercyclical labor share above. Lucas (1977) listed regularity of business cycle in section 2 that "Production of producer and consumer durables exhibit much greater amplitude than does the production of nondurables" and "Business profits show high conformity and much greater amplitude than other series." Nolan (1987) also confirmed that profit is the factor income which is most responsive to cyclical fluctuation. To summarize, the fluctuation magnitude of investment and profit is greater than employment and wage. The fourth index and the fifth index show that capital share rises and labor share falls if the slope of the curve of labor-capital ratio is concave (i.e., capital-labor ratio is convex). Besides, the third index is also a method to test the production function we estimate because marginal product and capital-labor ratio derived from the production function, which we derive from economic model (e.g., maximum return rate on capital hypothesis), must fit into capital share and labor share we observed.

It is worth noting that labor share rose from 1901 to 1945 in Piketty (2014), which cannot be explained by Piketty's second law (change in the ratio of propensity to save to population growth rate) because these 50 years are opposite to the long term trend of declining labor share. Instead, countercyclical labor share in business cycles and wars can explain. There were recessions in 1907, 1913, 1921 and 1929. The great depression lasted for ten years in US, 1929-1939. The influence of two world wars on capital share is too great to be ignored. War destroys huge quantity of capital so that capital share should be extraordinarily low even aftermath. War needs additional man power to build up military force so that labor share rises. The First World War was from 1914 to 1918. The Second World War began at 1939 and ended at 1945 . The total war time in the first half of $20^{\text {th }}$ century was around ten years. In short, the first half of $20^{\text {th }}$ century was the age in turmoil so that labor share rose.

\section{Tendency of Rate of Profit to Fall}

Karl Marx argued that capitalists accumulate capital so that capitalists can employ less labor than before but produce the same quantity of output as before. Surplus-value is the difference between labor hours, which labor works, and wage, which is paid in terms of hours by capitalist. Consequently, surplus-value is less than before because the number of working hours is less than before and the percentage of working hours exploited by capitalist is no less than before. Since surplus-value is the source of profit and surplus-value declines continuously due to infinite capital accumulation, profit rate approximates to zero. Thus, Karl Marx concluded that capitalism is doomed to collapse. That is the theory of tendency of rate of profit to fall. Since Karl Marx 
addressed that capitalists transform money into commodity and then sell commodity to get money back (i.e., M-C-M in Capital Vol. I), profit in terms of money is equivalent to surplus-value in terms of labor time (i.e., profit is the appearance of surplus-value because surplus-value is unobservable but profit is observable in Capital Vol. III). Thus, it is unnecessary that every commodity must be expressed in terms of labor time instead of money when we investigate tendency of rate of profit to fall so that I can use growth theory of the firm to study tendency of rate of profit to fall.

Since the concept of profit rate in Capital of Karl Marx is different from the return rate on capital in this paper, I explain the concept of profit rate in Capital first. In Vol. I p. 317, Marx wrote "That part of capital, therefore, which is turned into means of production, i.e., the raw material, the auxiliary material and the instruments of labour, does not undergo any quantitative alternation of value in the process of production. For this reason, I call it the constant part of capital, or more briefly, constant capital." and "On the other hand, that part of capital which is turned into labour-power does undergo an alternation of value in the process of production. It both reproduces the equivalent of its own value and produces an excess, a surplus-value, which may itself, and be more or less according to circumstances. This part of capital is continually being transformed from a constant into a variable magnitude. I therefore call it variable part of capital, or more briefly, variable capital."

Certainly, constant capital involves fixed capital like tool, machine and building. Fixed capital itself is not the value added to product (i.e., quantitative alternation of value in the process of production) but depreciation is so that constant capital does not create value because the total value losing from fixed capital (i.e., depreciation) and intermediate goods is equal the total value added to outputs. Thus, constant capital is equivalent to the sum of depreciation and expenditure in intermediate goods in terms of money. Capitalists pay wage to employ labor and labor power is the only way to create value in the process of production under labor theory of value. Thus, variable capital is equivalent to wage expenditure. The sum of constant of capital and variable capital is the total cost to produce a certain quantity of outputs. Since capitalists pay wage by subsistence and the difference between total value before process of production and total value after process of production is equal to wage expenditure plus surplus-value (i.e., labor value), profit is equivalent to surplus-value. Let $s, C$ and $V$ be surplus-value, constant capital and variable capital. Kael Marx defined surplus-rate (i.e., profit rate)

$$
\frac{s}{C+V}=\text { surplus }- \text { rate }=\frac{\text { total prof it from sales of product }}{\text { total cost of production }}
$$

In order to study surplus-rate, I modify my model in order to concern depreciation. $d$ is depreciation rate. If production function is increasing return to scale, depreciation rate declines as quantity of output increases because marginal product of capital increases. $d Q$ is total amount of depreciation. $w N$ is variable capital. $\zeta$ is surplus-rate. Notice that I ignore intermediate goods in this paper.

$$
\begin{gathered}
\operatorname{Max} \gamma=\frac{(P-c) Q-w N-d Q}{K} \\
\operatorname{Max} \zeta=\frac{s}{C+V}=\frac{(P-c) Q-w N-d Q}{d Q+w N} \\
\frac{\partial \zeta}{\partial K}=\frac{\left((P-c-d)+\frac{\partial P-c-d}{\partial Q} Q\right) \frac{\partial Q}{\partial K}(d Q+w N)-d \frac{\partial Q}{\partial K}((P-c-d) Q-w N)}{(d Q+w N)^{2}}=0\left(i . e ., \zeta=\frac{P-c-d+\frac{\partial P-c-d}{\partial Q} Q}{d}\right)
\end{gathered}
$$

Equation (34) defines surplus-rate in terms of money. If the maximum surplus-rate is equal to zero, then equation (35) requires that price elasticity should be one. The firm does not intend to move toward the position on which price elasticity is equal to one because marginal revenue is equal to zero so that this movement does not improve the situation that the firm was. In other words, rational economic agent is not on optimal position when price elasticity is equal to one. Since $\eta=-1$ is contrary to the premise of profit pursuing, the theoretical framework of Capital is illogical. Besides, we cannot determine wage, return rate on capital, price and quantity of output by surplus-rate.

What does the ratio of marginal revenue to depreciation rate mean? Since the result of equation (35) is ambiguous, I transform the concept of surplus-rate defined by Karl Marx into

$$
\frac{\frac{\text { total profit fom sales of product }}{Q}}{\frac{\text { total cost of production }}{Q}}=\text { profit rate of a single unit product }
$$

Since marginal revenue is related to the net sale revenue of an extra single unit product sold in market, equation (35) means that profit rate of a single unit product is equal to marginal revenue divided by depreciation rate if the firm pursues maximum profit rate of a single unit product by adjusting volume of capital. What will happen to profit rate of a single unit product under increase in demand? 


$$
\frac{\partial \frac{(P-c-d) Q-w N}{d Q+w N}}{\partial c}=-\frac{Q}{d Q+w N}<0
$$

As equation (29) shows that return rate on capital rises when economy grows, profit rate of single unit product rises (falls) as demand increases (decreases). Since production function is increasing return to scale so that labor productivity rises, labor time in a single unit product declines continuously. But we cannot conclude that surplus-rate diminishes when surplus-value of a single unit product reduces because productivity of capital under increasing return to scale rises so that $d$ (depreciation rate) declines under increasing return to scale, which makes depreciation in equation (34) declines (i.e., constant capital in a single unit product decreases). I demonstrate that increasing return is the reason why we get equation (36).

$$
\begin{gathered}
\frac{(P-c-d) Q(t K, t N)-w t N}{d Q(t K, t N)+w t N}-\frac{(P-c-d) Q(K, N)-w N}{d Q(K, N)+w N} \\
=\frac{\left[(P-c-d) t^{m} Q(k, N)-w t N\right](d Q(K, N)+w N)-[(p-c-d) Q(K, N)-w N]\left(d t^{m} Q(K, N)+w t N\right)}{\left(d t^{n} Q(K, N)+w t N\right)(d Q(K, N)+w N)} \\
(P-c-d) t^{m} Q(K, N) w N-w t N d Q(K, N)-\left((P-c-d) Q(K, N) w t N-w N d t^{m} Q(K, N)\right) \\
=(P-c-d) Q(K, N) w N\left(t^{m}-t\right)+w N d Q(K, N)\left(t^{m}-t\right)>0 \text { if } m=\frac{1}{1+\frac{1}{\eta}}>1 \text { and } t>1
\end{gathered}
$$

Equation (37) concerns the difference between profit rate of single unit product under flexible scale $Q(t K, t N)$ and under given scale $Q(K, N)$. Equation (38) demonstrates that profit rate of single unit product under flexible scale is greater than given scale if production function is increasing return to scale.

Since Karl Marx concerned change in capital-labor ratio and diminishing marginal product of capital under capital accumulation but ignored scale growth of the firm, the economic theory contributed by Karl Marx is similar to growth theory of neoclassical economics. Since the firm grows by scale, it is a wrong conclusion made by Marxists that capitalism collapses endogenously and inevitably because tendency of rate of profit to fall is an inherent property of capitalism naturally. Since Karl Mark did not realize that both size of the firm and quantity of output are limited by limited market demand so that capital accumulation, depreciation and expenditure in intermediate goods (constant capital) do not increase infinitely, numerical examples that demonstrate that capital accumulation leads to tendency of rate of profit to fall in Capital Vol. III 3 Chapter 13 are not mathematical proof of tendency of rate of profit to fall derived from production function and market demand logically as I disprove tendency of rate of profit to fall above but illustrations written by Karl Marx arbitrarily in order to present what is the meaning of tendency of rate of profit to fall numerically instead of verbally.

\section{Conclusion Remarks}

Maximum return rate on capital hypothesis is the corner stone of this paper because maximum return rate on capital hypothesis is the cause (independent and exogenous variable) to determine employment, reward and marginal product of each input factor, which are all effect (dependent and endogenous variables). Effect explains nothing. For example, we cannot use wage rate to explain employment and vice versa under maximum return rate on capital hypothesis. In other words, relationships among dependent variables are not causation but mathematical mapping. Thus, this paper demonstrates that quantity of input factor (e.g., capital abundant), reward to each input factor (e.g., return rate on capital) and marginal product explain neither capital outflow nor declining labor share so that both Lucas (1990) and Piketty (2014) are wrong because they used dependent variables to explain economic phenomena we observe.

Scale growth, increasing return to scale and marginal revenue are three essential characteristics which distinguishes growth theory of the firm from growth theory of neoclassical economics. I derive five conclusions from growth theory of the firm. First, return rate on capital and wage rate are different from marginal product of capital and marginal product of labor respectively due to diminishing marginal revenue so that wage growth rate and profit growth rate are less than growth rate of labor productivity and growth rate of capital productivity respectively. Noticed that both productivity and marginal product are supposed to regard quantity in physical terms (e.g., piece and pound) while wage and profit are in terms of money. Since the production function (equation (14)) in this paper refers to quantity in physical terms instead of in terms of money because price and quantity are separated when I analyze production function, this paper denies the approach in growth theory of neoclassical economics that reward on each input factor is equal to its marginal product.

Second, production function applied by the firm is increase return to scale instead of constant return to scale. Third, I demonstrate that both marginal product of capital and marginal product of labor would increase rather 
than decrease when the firm grows by scale because of increasing return to scale. Implicitly, marginal product of capital, return rate on capital, marginal product of labor and wage rate in rich (large) country are all greater than poor (small) country. Thus, both Lucas paradox and tendency of rate of profit to fall are wrong. Fourth, I show that labor (capital) share is countercyclical (cyclical) in the short run so that both labor share and capital share fluctuate up and down as well as labor share is equal to capital share in the long run under the circumstance of perfect substitutability between capital and labor. Thus, the long term declining labor share is domestic and global because labor share is empirically greater than 50 percent of GDP (i.e., there is room to substitute capital for labor because labor is relatively more expansive (less productive) than capital due to exogenous constraint of substitutability by technology). Fifth, scale growth implies that we will not observe diminishing marginal product in real world.

It is worth noting that Young (2004) followed real business cycle theory to explain countercyclical labor share by biased technology shock. Technology must be deteriorated during recession if real business cycle theory is true; otherwise, marginal product will not decline during recession. But we do not observe physical technology deterioration during recession so that economists criticized real business cycle theory. Besides, Hall (1990) also found that increasing return to scale makes productivity cyclically so that Hall concluded that real business cycle is a false theory. Since increasing return to scale explains why marginal product descends during recession and ascends during boom without technology progress, Young misinterpreted the decrease in marginal product during recession caused by increasing return to scale for technology deterioration shock. It is worth noting that real business cycle theory and growth theory of the firm are opposite in the sense of theoretical framework. Real business cycle theory states that technology shock (i.e., exogenous change in productivity) causes business cycle so that productivity and quantity of output are positively correlated. Growth theory of the firm demonstrates that productivity and quantity of output are positively correlated in the sense of statistics instead of causation because change in productivity is cyclical endogenously due to increasing return to scale so that cyclical productivity is not independent variable to cause business cycle exogenously but dependent variable observed by us endogenously during business cycle.

If capital and labor are not fully substitutable due to technology constraint (e.g., I mentioned in section 1 that elasticity of substitution between capital and labor is less than one), price mechanism (return rate on capital and wage rate) cannot perfectly equalize labor share and capital share by price substitution effect so that labor share may be greater or less than capital share when economy reaches equilibrium in the long run. There are two kinds technical progress. First, technical progress brings about new goods which imply new capital-labor ratios and new marginal productivities exogenously. In other words, labor share and capital share are random among industries. Lawrence (2015, p.25-6) listed labor share of petroleum refine (43.2 percent), chemical product (49.6 percent) and computer and electronics ( 81.7 percent) at 1987. It is easy to recognize that labor share is random among industries because labor cannot replace capital in chemical and petroleum industry while capital cannot replace labor in computer and electronic industry technically. Thus, wage rate and return rate on capital cannot erase difference in labor share among industries by price substitution effect. Second, technical progress improves technological substitutability between capital and labor in each industry on the purpose of cost down. Labor share of these three industries above became 12.2 percent, 35.2 percent and 57.7 percent respectively at 2011. Obviously, capital substitutes labor in each industry. Technical progress of technological substitutability not only equalizes of labor share and capital share rapidly in computer and electronic industry but also further replaces labor by capital in petroleum and chemical industries. Technical progress may raise labor share if new technology needs more human capital than before, e.g., computer and electronics at 1987. Lawrence (2015, p.20) also reported that labor share in education, health care and government rose. It is worth noting that land is capital of agriculture and land rent was high before industrial revolution so that land rent accounts for why labor share before industrial revolution is not much higher than recent labor share although capital could not replace great deal of labor and depreciation of capital was relatively trivial before industrial revolution.

This paper requires that economists should empirically test conclusions of this paper by firm's data. GDP contains government sector. Government does not pursue maximum return rate on capital so that government is easily oversized and then labor share in GDP is biased by the size of government. Further, GDP regards both consumption and production while tendency of rate of profit to fall, Lucas paradox and declining labor share refer to production only. Consequently, consumption makes GDP be biased data to test conclusions derived from growth theory of the firm. For example, petroleum is intermediate goods for firms to produce and transport so that petroleum growth rate is less than GDP growth rate (i.e., petroleum growth rate and GDP growth rate are negatively correlated) under increasing return to scale. But household consumption in gasoline for driving may make petroleum growth rate be higher than GDP growth rate (i.e., petroleum growth rate and GDP growth rate 
are positively correlated). Thus, we are going to get biased results if we use GDP and petroleum to test increasing return to scale.

Further, the negative correlation between input growth rate and GDP growth rate misleads economists to concern the possibility that GDP data is biased by either inappropriately statistical method or political manipulation. Subramanian (2019, P.7), who concerned India's GDP Mis-estimation, found that 16 of 17 indexes are positively correlated with GDP growth rate (e.g., electricity) before 2011 but 11 of 17 indexes are negatively correlated GDP growth rate (e.g., petroleum) after 2011. Rawski (2001) believed that China's GDP statistics is overestimated because GDP grew 24.7 percent but energy consumption dropped 12.8 percent from 1997 to 2000 while efficiency of energy conversion is not improved. Since both China and India are not only big country so that scale is large but also developing country so that energy consumption by household is low relative to developed country, negative correlation between growth rate of energy consumption and GDP growth rate will be apparent. Thus, the bias of GDP statistics of China and India seems to be exaggerated by the negative correlation between input growth rate and GDP growth rate. It is worth noting that I predict that the recent growth rate of petroleum and growth rate of GDP in China is supposed to become positive because passenger automobile has grown fast recently in China. Thus, we cannot argue that the recently positive correlation between growth rate of petroleum and GDP growth rate in China is the evidence to prove that previously negative correlation between growth of petroleum and GDP growth rate in China is false due to political manipulation.

Ting (2014) demonstrated that factor price is not equalized while the firm size is given. This paper shows that both marginal product of capital and marginal product of labor of the firm in large market are greater than small market due to increasing return to scale. Thus, absolute factor prices in large country are higher than small country due to increasing return to scale. In other words, absolute factor price is not equalized under increasing return to scale. Further, industries of labor intensive goods in capital abundant and large country may be more productive than labor abundant and small country (e.g., US agricultural products versus Japan agricultural products) and industries of capital intensive goods in labor abundant and large country may be more efficient than capital abundant and small country (e.g., China exports steel to US). Thus, increasing return to scale explains Leontief (1953).

Large country is supposed to have trade surplus because large country has productivity advantage in every industry due to increasing return to scale. But David Ricardo (1817) developed theory of comparative advantage in which Portugal has absolute cost advantage in both wine industry and cloth industry over England but Portugal will export wine and import cloth. In other words, relative price makes international trade be balanced even two countries have different technology (productivity). Consider a case of two countries, say A and B, and three goods, say X, Y and Z. Relative prices or opportunity cost on production possibility frontier in country A (B) are 1:2:4 (1:3:3). In this case, country A exports $\mathrm{X}$ and imports $\mathrm{Y}$ but country $\mathrm{A}$ also exports $\mathrm{Z}$ and imports not only $\mathrm{X}$ but also $\mathrm{Y}$. Thus, we get a contradictory conclusion that country A not only exports $\mathrm{X}$ but also imports $\mathrm{X}$. Concern another case in which there are three countries, say A, B and C, and two goods, say X and Y. Combinations of relatives prices are (1:2), (1:3) and (1:4) respectively so that country B not only imports $\mathrm{X}$ from country A but also exports $\mathrm{X}$ to country $\mathrm{C}$ depending on how many unit of product $\mathrm{Y}$ country A needs and how many unit of product $Y$ country $\mathrm{C}$ can export. To summarize, economists accept David Ricardo's argument that comparative advantage, based on relative price approach, leads to balanced trade because economists do not understand that we cannot use relative price to analyze economic issue (e.g., Ting (2018) and this paper shows that we cannot use ratio of marginal product of labor to marginal product of capital to infer the absolute wage rate and absolute return rate on capital).

Finally, readers should not confuse the failure of tendency of rate of profit to fall with the failure of communism and the success of capitalism. Ernest Mandel provided an outstanding argument in the introduction to Capital Vol. III published by Penguin 1990. In P. 87, Ernest Mandel argued that automation makes continuously capital accumulate and profit rate fall so that capitalism is doomed to collapse. But automation does not disprove the relationship between return rate on capital and growth theory of the firm developed in this paper because growth theory of the firm in this paper is built on effective market demand (i.e., shifting in market demand curve) - how much buyers plan to pay and how many outputs buyers plan to purchase. If effective market demand is limited, return rate on capital will not fall continuously because the size of the firm (i.e., capital accumulation) is limited by limited effective market demand and maximum return rate on capital hypothesis although production method is automation and increasing return to scale.

But Mandel's argument inspires me to realize that full automation implies that the firm does not employ labors anymore so that labors have neither job nor means of production to yield income and then pay for their living 
expenditure individually (i.e., yield income to form effective demand of individual person). Consequently, capitalism that is based on private property right to distribute income into input factors collapses because labor receives noting so that labor rebels for survive. Alternatively, administration of political authority based on collective property right and military force can distribute purchasing power into each member of society in order to form effective demand of individual person and effective market demand while price mechanism also allocates resources to construct efficient market supply instead of centralization. For example, political authority pursues maximum return rate on capital under communism in order to allocate resources efficiently because the combination of price and return rate on capital reflects the eagerness of demand for a particular product. Besides, income can be distributed into each member in community by his own contribution in communism. For instance, a person invents a new machine so that this person is allowed to share profit. That is, price mechanism operates under collective property right. The key point of communism is that personal saving is not permitted to be converted into means of production but personal saving is allowed to be consumed in the future (e.g., big house and luxury car). Thus, communism operates under full automation and price mechanism while capitalism does not. To summarize, this paper argues that each economic structure (e.g., capitalism and communism) is suitable to a particular economic environment (e.g., full automatic production). In other words, economic structure changes when economic environment changes. That is, economic structure evolves.

\section{References}

Antràs, P. (2004). Is the U.S. Aggregate Production Function Cobb-Douglas? New Estimates of the Elasticity of Substitution. Contribution to Macroeconomics, 4, 1-34. https://doi.org/10.2202/1534-6005.1161

Bernanke, B., \& Parkinson, M. (1991). Procyclical Labor Productivity and Competing Theories of Business Cycle: Some Evidence from Interwar U.S. Manufacturing Industries. Journal of Political Economy, 199, 439-459. https://doi.org/10.1086/261761

Diewert, W. (1971). An Application of Shephard Duality Theory: A Generalized Leontief Production Function. Journal of Political Economy, 79, 481-507. https://doi.org/10.1086/259764

Diewert, W. (2018). Duality in Production. Discussion Paper 18-02, Vancouver School of Economics, University of British Columbia.

Domar, E. (1947). Expansion and employment. American Economic Review, 37, 34-55. https://doi.org/10.1086/256541

Duffy, J., \& Papageorgiou, C. (2000). A Cross-Country Empirical Investigation of the Aggregate Production Specification. Journal of Economic Growth, 15, 87-120. https://doi.org/10.1023/A:1009830421147

Fuss, M., McFadden, D., \& Mundlak, Y. (1978). A Survey of Functional Forms. In F. Melvyn, \& M. Daniel (Eds.), Production Economics: A Dual Approach to Theory and Application. Amsterdam: North Holland.

Grabowski, R., \& Sanchez, D. (1986). Returns to scale in agriculture: An empirical investigation of Japanese experience. European Review of Agricultural Economics, 13, 189-198. https://doi.org/10.1093/erae/13.2.189

Hall, R. (1990). Invariant Properties of Solow's Productivity Residual. In P. Diamond (Ed.), Growth, Productivity, Employment. Cambridge MIT press. https://doi.org/10.3386/w3034

Jones, C. (2014). Macroeconomics of Piketty. Stanford University.

Klette, J., \& Zvi, G. (1996). The Inconsistency of Common Scale Estimators When Output Prices Are Unobserved and Endogenous. Journal of Applied Econometrics, 11, 343-361. https://doi.org/10.1002/(SICI)1099-1255(199607)11:4<343::AID-JAE404>3.0.CO;2-4

Krugman, P. (1979). Increasing Returns, Monopolistic Competition and International Trade. Journal of International Economics, 9, 469-479. https://doi.org/10.1016/0022-1996(79)90017-5

Krugman, P. (1991). Increasing Returns an Economic Geography. Journal of Political Economy, 99, 483-499. https://doi.org/10.1086/261763

Krusell, P., \& Smith, T. (2014). Is Piketty's "Second Law of Capitalism" Fundmetnal? Institute for International Economic Studies Manuscript.

Lawrence, R. (2015). Recent Declines in Labor's Share in US Income: A Preliminary Neoclassical Account. NBER Working Paper, 21296. https://doi.org/10.3386/w21296

Leontief, W. (1953). Domestic Production and Foreign Trade; The American Capital Position Re- Examined. 
Proceedings of American Philosophical Society, 97, 332-349.

Lernald, J., \& Wang, C. (2016). Why Has the Cyclicality of Productivity Changed: What Does It Mean? Federal Reserve Bank of San Francisco, Working Paper 2016-07. https://doi.org/10.24148/wp2016-07

Liu, A., Gao, G., \& Kaizhong, Y. (2011). Return to scale in the production of selected manufacturing sectors in China. Energ Procedia, 5, 604-612. https://doi.org/10.1016/j.egypro.2011.03.106

Lucas, R. (1977). Understanding Business Cycle. In K. Brunner, \& A. Meltzer (Eds.), Stabilization of the Domestic and International on Economy, Vol. 5 of Carnegie-Rochester Series on Public Policy (pp. 7-29). Amsterdam: North-Holland Company. https://doi.org/10.1016/0167-2231(77)90001-X

Lucas, R. (1990). Why doesn't Capital Flow from Rich to Poor Countries. American Economic Review, 80, 92-96.

Marx, K. (1990). Capital, Translated by Ben Fowkes. Introduced by Ernest Mandel, Reprinted in Penguin.

Morrison, C., \& Seigel, D. (1997). External Capital Factors and Increasing Returns in U.S. Manufacturing. Review of Economics and Statistics, 79, 647-654. https://doi.org/10.1162/003465397557051

Noton, B. (1987). Cyclical Fluctuations in Factor Shares and Size Distribution of Income. Review of Income and Wealth, 33, 193-209. https://doi.org/10.1111/j.1475-4991.1987.tb00670.x

Oliveira, F., Jayme, F., \& Lemos, M. (2006). Increasing returns to scale and international diffusion of technology: An empirical study of Brazil (1976-2000). World Development, 34, 75-88. https://doi.org/10.1016/j.worlddev.2005.07.011

Piketty, T. (2014). Capital in the Twenty-First Century. Cambridge: Belkanp Press. https://doi.org/10.4159/9780674369542

Rawski, T. (2001). What is happening to China's GDP statistics. China Economic Review, 12, 347-354. https://doi.org/10.1016/S1043-951X(01)00062-1

Ricardo, D. (1821). On the Principle of Political Economy and Taxation (3rd ed.). Library of Economics and Liberty 1999.

Rognlie, M. (2014). A Note on Piketty and Diminishing Returns to Capital. MIT.

Rognlie, M. (2015). Deciphering the Fall and Rise in the Net Capital Share: Accumulation or Scarcity. Brookings Paper on Economic Activity. https://doi.org/10.1353/eca.2016.0002

Romer, P. (1986). Increasing Returns and Long-Run Growth. Journal of Political Economy, 94, 1002-1037. https://doi.org/10.1086/261420

Schneider, D. (2011). The Labor share: A Review of Theory and Evidence. SFB 649 Discussion Paper No. 2011-069.

Simon, H., \& Levy, F. (1963). A Note on the Cobb-Douglas Function. Review of Economic Studies, 30, 993-994. https://doi.org/10.2307/2295806

Solow, R. (1956). A contribution to the theory of economic growth. The Quarterly Journal of Economics, 70, 65-94. https://doi.org/10.2307/1884513

Solow, R. (1957). Technical Change and the Aggregate Production Function. The Review of Economics and Statistics, 39, 32-320. https://doi.org/10.2307/1926047

Subramanian, A. (2019). India's GDP Mis-estimation: Likelihood, Magnitudes, Mechanisms and Implications. CID Faculty Working Paper, No. 354.

Ting, C. C. (2010). The Optimum Size of the Firm and Growth Theory. European Journal of Economics, Finance and Administrative Science, 25-28.

Ting, C. C. (2012). Market Value of the Firm, Market Value of Equity, Return Rate on Capital and Optimal Capital Structure. International Journal of Financcial Research, 3, 1-6. https://doi.org/10.5430/ijfr.v3n4p1

Ting, C. C. (2014). A Note on Factor Price Equalization. Business and Economics Journal. https://doi.org/10.4172/2151-6219.1000085

Ting, C. C. (2018). Phillips Curve is a Particular Case That Economists Misinterpret the Correlation Between Two Dependent Variables for Causal Relation. International Journal of Economics and Finance, 10(11), 70-94. https://doi.org/10.5539/ijef.v10n11p70 
Vergos, K., Apostotos, C., Panagiotis, K., \& Olga, P. (2010). Economies of scale and concentration in the Greek and the Norwegian Agriculture Industry: An empirical study. International Journal of Business, Management and Economics Research, 1, 70-78.

Wheelock, D., \& Wilson, P. (2009). Do Large Banks Have Lower Cost? New Estimates of Return to Scale for U.S. Banks. Federal Bank o St. Louis, Working Paper 2009-054E. https://doi.org/10.20955/wp.2009.054

$\mathrm{Xi}, \mathrm{C}$. (2015). Increasing returns to scale in U.S. manufacturing industries: Evidence from direct and reverse regressions. Retrieved from https://afse2015.sciencesconf.org/61626/document

Young, A. (2004). Labor's Share Fluctuations, Biased Technological Change and the Business Cycle. Review of Economic Dynamics, 7, 916-937. https://doi.org/10.1016/j.red.2004.07.001

\section{Note}

Note 1. Jesus Felipe and J. S. L. McCombie have published many papers to discuss and review the problem of aggregate production function in terms of money, especially "HOW SOUND ARE THE FUNDATION OF THE AGGREGATE PRODUCTION FUNCTION,” Eastern Economic Journal, Vol. 31, pp. 467-488, 2005.

\section{Appendix}

The purpose of this appendix is to demonstrate that Taylor series is the true specification of regression for economists to estimate production function statistically. In the beginning, I derive $Y=\frac{\partial Y}{\partial N} N+\frac{\partial Y}{\partial K} K$ from maximum profit hypothesis and competitive market in order to show that properties of production function depend on economic model. Where $Y$ is aggregate output in terms of money or GDP. Consequently, we cannot identify the true specification of production function in real world by economic theory and econometrics because there are many economic models which are valid. It implies that there is no reason to accept any particular specification (e.g., Cobb-Douglas function) to statistically estimate production function if we intend to estimate the true production function in real world. Thus, we should use Taylor series to approximate the true production function in real world instead of determination of the specification of production function by properties of production function derived from economic theory, e.g., Diewert (1971) used cost function and Shephard duality to determine functional form (i.e., specification) of production function.

Assume that the firm pursues maximum profit in competitive market and produces different products. We get

$$
\begin{gathered}
\operatorname{Max} Y(N, K)-w N-R K \\
\frac{\partial Y}{\partial N}=w \\
\frac{\partial Y}{\partial K}=R \\
Y=w N+R K=\frac{\partial Y}{\partial N} N+\frac{\partial Y}{\partial K} K
\end{gathered}
$$

$Y$ represents aggregate output of the firm. Like GDP, aggregate output of the firm is valued by total sales because there is no common unit to measure aggregate output except money. $R$ is rental price, which is the opportunity cost of capital, because the firm can rent capital instead of purchase. Since profit is zero in competitive market, total sales revenue must be equal to the sum of wage expenditure and rental expenditure, $Y=w N+R K$. Thus, $Y=\frac{\partial Y}{\partial N} N+\frac{\partial Y}{\partial K} K$ is derived from $Y=w N+R K$ (i.e., derived from competitive market, not maximum profit hypothesis). $Y=\frac{\partial Y}{\partial N} N+\frac{\partial Y}{\partial K} K$ requires that product function should be homogenous degree one (i.e., constant return to scale). But this conclusion is not universally true under maximum profit hypothesis. For example, $Y-w N$ (i.e., the concept of profit is defined to be the residual that sale revenue minus cost 
expenditure) if we assume that market is monopoly and the firm purchases capital. Although wage rate is equal to marginal product of labor in this case, we cannot derive that return on capital is equal to marginal product of capital from $\operatorname{Max} Y-w N$. In addition, it is another example that I derive $Q=\left(1+\frac{1}{\eta}\right)\left(\frac{\partial Q}{\partial N} N+\frac{\partial Q}{\partial K} K\right)$ from maximum return rate on capital hypothesis. Thus, we are not able to identify the true specification of production function in real world by economic model.

All aggregate production functions that fits equation (A4) is linear so that all production functions of homogenous degree one fit GDP. Under this circumstance, economists neither reject constant return to scale nor identify the true specification of production function by statistical testing. For example, CES and Cob-Douglas are supposed to be equivalent in the sense of statistical testing so that we do not know the true production function is CES or Cobb-Douglas by statistical testing. Both Shaikh (1974) and Simon and Levy (1963) recognized that aggregate output in terms of money like GDP causes constant return to scale (e.g., equation (A4)) so that we face identification problem of production function because all functions of homogenous degree one are supposed to fit data of GDP well. It implies that value-added aggregate output may lead scale estimator to be underestimated statistically (i.e., lead economists to reject increasing return to scale). This issue was exhibited in section 2 when I discussed result of Klette and Griliches (1996).

Each form of production function has its own fundamental properties. Suppose the form of production is Cobb-Douglas, $Y=N^{\alpha} K^{\beta}$. $\alpha$ is labor share and $\beta$ represents capital share. Thus, $\alpha+\beta=1$ because the sum of income shares must be one. Thus, the form of Cobb-Douglas production function implies constant return to scale. In other words, Cobb-Douglas production function is inconsistent with increasing return to scale. But, empirical studies show that $\alpha>1$ frequently so that Bernanke and Parkinson (1991) used $\alpha>1$ to conclude that increasing return to scale accounts for procyclical labor productivity and reject real business cycle theory in which technology shocks explain procyclical labor productivity. Since $\alpha>1$ and Cobb-Douglas production function fits data well, Cobb-Douglas production function violates one of its own fundamental properties, $\alpha<1$. Thus, economists should reject Cobb-Douglas production function as Sebastian et.al (2019), Antràs (2004) and Duffy and Papapeorgiion (2000) did. Some economists (e.g., Diewert, 1971) attribute the failure of econometric prediction based on the idea of production function to the ignorance of the true functional form (i.e., true specification) of production function and intend to determine functional form of production function by its properties derived from economic model. But economists do not realize that properties of production function depend on economic model selected by economists so that the approach of functional form does not take care of misspecification of production function actually.

Further, Diewert (1971) derived restrictions from cost function because minimum cost and maximum profit is dual. In duality, cost function is the sum of expenditure on input factors so that cost function depends on quantity and price of each input factor. If there is increasing return to scale, cost depends on scale in addition to quantity and price. Thus, we cannot derive all necessary restrictions from duality to get true specification of production function because Diewert omitted scale in cost function. In other words, Diewert (1971) is a special theory to estimate production function under given scale because maximum profit is a special case of maximum return rate on capital due to the reason that scale is given in maximum profit hypothesis implicitly.

Taylor series means that we can approximate any mathematic function by polynomial function. Thus, we can use Taylor series to approximate true production function because the true functional form of production function is unnecessary to be known when we estimate production function by Taylor series statistically. Compare $Y=\frac{\partial Y}{\partial N} N+\frac{\partial Y}{\partial K} K$ with $P Q=P\left(1+\frac{1}{\eta}\right)\left(\frac{\partial Q}{\partial N} N+\frac{\partial Q}{\partial K} K\right) . Y=\frac{\partial Y}{\partial N} N+\frac{\partial Y}{\partial K} K$ omits price elasticity, concerned by Klette and Griliches (1996), while price elasticity implies increasing return to scale. No input, no output. Thus, $f(0,0)=0$. It is the key point of this appendix that $Y=\frac{\partial Y}{\partial N} N+\frac{\partial Y}{\partial K} K$ is Taylor series expanding at point $(0,0)$ for any two variables linear production function so that $Q=\left(1+\frac{1}{\eta}\right)\left(\frac{\partial Q}{\partial N} N+\frac{\partial Q}{\partial K} K\right)$ needs at least second order Taylor series to approximate. Thus, production function is not linear if the second order of Taylor series estimated by us statistically is not equal to zero. 


$$
\begin{gathered}
Q=f(N, K)=\frac{\partial f}{\partial N} N+\frac{\partial f}{\partial K} K+\frac{1}{2 !}\left(\frac{\partial^{2} f}{\partial N^{2}} N^{2}+2 \frac{\partial^{2} f}{\partial N \partial K} N K+\frac{\partial^{2}}{\partial K^{2}} K^{2}\right)+\frac{1}{3 !} \ldots \cdot . \\
\frac{\partial \frac{\partial f}{\partial N}}{\partial K}=\frac{\partial^{2} f}{\partial N \partial K}=\frac{\partial \frac{\partial f}{\partial K}}{\partial N}
\end{gathered}
$$

Equation (A5) is expansion of Taylor series at the point $(0,0) \cdot \frac{\partial^{2} f}{\partial N^{2}}$ and $\frac{\partial^{2} f}{\partial K^{2}}$ regards change rate in marginal product. Since the law of diminishing marginal product does not operate due to scale growth, change rate of marginal product is supposed to be insignificant statistically. Thus, $\frac{\partial^{2} f}{\partial N \partial K}$ must be positive theoretically and significant statistically if production function is increasing return to scale because marginal product increase under scale growth if production function is increasing return to scale and equation (A6) concerns the relationship between marginal product of labor (capital) and change in capital (labor). It is worth noting that this relationship expressed by the second order of Taylor series may disappear after mathematic transformation. For example, marginal product of labor depends on volume of capital in $N^{\alpha} K^{\beta}$ but marginal product of labor $\left(\frac{\partial \log Y}{\partial \log N}\right)$ in $\log Y=\alpha \log N+\beta \log K$ is independent of capital $\left(\frac{\partial^{2} \log Y}{\partial \log N \partial \log K}=0\right)$. It is wrong that we assume a particular functional form (e.g., Trans Log and Cobb-Douglas) first and then we expand Taylor series based on this particular functional form next when we estimate production function statistically.

$$
\begin{gathered}
f(x)=f(a)+f^{\prime}(a)(x-a)+\frac{1}{2 !} f^{\prime \prime}(a)(x-a)^{2} \ldots \\
f(x)=f(b)+f^{\prime}(b)(x-b)+\frac{1}{2 !} f^{\prime \prime}(b)(x-b)^{2} \ldots \\
f^{\prime}(b)=\frac{f(b)-f(a)}{b-a} \\
f^{\prime \prime}(b)=\frac{f^{\prime}(b)-f^{\prime}(a)}{b-a}
\end{gathered}
$$

Since $f(0), f^{\prime}(a) \ldots f^{n}(a), f^{\prime}(b) \ldots$ and $f^{n}(b)$ are coefficients estimated by us statistically, we can test equation (A9) and equation (A10). If this test fails, it implies that samples we collect contains at least two different production functions, e.g., $f(x)=f(0)+f^{\prime}(a)(x-a)+\frac{1}{2 !} f^{\prime \prime}(a)(x-a)^{2} \ldots$ from period 0 to $t$ and $g(x)=g(0)+g^{\prime}(b)(x-b)+\frac{1}{2 !} g^{\prime \prime}(b)(x-b)^{2} \ldots$ from period $t+1$ to $n$. Since technical progress requires that the volume of output should increase while the volume of input is given (i.e., marginal product of input factor should increase), technical progress implies that production function changes. Thus, technology progresses if the test of equation (A9) and equation (A10) fails.

Let input grows from $(n, k)$ to $(N, K)$. The test of increasing return to scale will be

$$
\begin{array}{r}
f_{N}^{\prime}(N, k)=\frac{f(N, k)-f(n, k)}{N-n} \\
f_{K}^{\prime}(n, K)=\frac{f(n, K)-f(n, k)}{K-k} \\
f_{N K}^{\prime \prime}(N, K)=\frac{f_{N}^{\prime}(N, K)-f_{N}^{\prime}(N, k)}{K-k} \\
f_{K N}^{\prime \prime}(N, K)=\frac{f_{K}^{\prime}(N, K)-f_{K}^{\prime}(n, K)}{N-n}
\end{array}
$$

Diewert (2018) suggested a topic for further investigation in the field of functional form: how to distinguish effect of increasing return to scale on marginal product from effect of technical progress on marginal product. This appendix shows that Taylor series can distinguish because $\partial^{2} f / \partial N \partial K$ in Taylor series estimated by us represents return to scale and changes in derivatives in Taylor series estimated by us imply technical progress. 
Fuss et al. (1978) rejected the idea that we apply Taylor series to estimate production function due to the reason that we have to approximate production function by expanding Taylor series in a small neighborhood while value of economic sample is so large that approximation by Taylor series is doomed to fail. We can overcome this problem by normalizing sample values because Fuss et.al did not recognize that the Taylor series of homogenous function is invariant.

$$
f(t x)=t^{m} f(x)=t^{m}\left(f(0)+f^{\prime} x+\frac{1}{2 !} x^{2} \ldots\right)
$$

For example, U.S. Nominal GDP is 0.105 trillions $\left(0.105 \times 10^{12}\right)$ in 1929 and 21.429 trillions $\left(21.429 \times 10^{12}\right)$ in 2019. In this case, the range of $x$ is $(0.105,21.429)$ and $t$ is equal to $10^{12}$. Of course, we can improve the accuracy of Taylor series further by shrinking the range of $x$ to be $(0.00105,0.21429)$ and raising $t$ to be $10^{14}$. Notice that scale growth is the key point by which equation (A15) makes sense so that Taylor series is capable to approximate aggregate production function like GDP.

\section{Copyrights}

Copyright for this article is retained by the author(s), with first publication rights granted to the journal.

This is an open-access article distributed under the terms and conditions of the Creative Commons Attribution license (http://creativecommons.org/licenses/by/4.0/). 